intestine of the holoxenic rat. In each group of rats, the bile acid composition observed in the small intestine and in the bile is different.

When holoxenic and gnotoxenic rats were provided with a jejunal self-filling blind loop, an increase in the faecal excretion of fat took place together with a decrease in the amount of conjugated bile acids at the level of small intestine. Deoxycholic acid was not observed in the gnotoxenic rat : therefore, presence of deoxycholic acid does not appear to be necessary to the development of steatorrhea in the blind loop syndrome.

Forty-eight hours after interruption of the entero-hepatic cycle, the biliary bile acid composition in the axenic rats and in the holoxenic rats were found to be similar : particularly, similar relative amounts of cholic acid and $\beta$-muricholic acid were observed in both groups. As a result, in the bile of the axenic rat, the amount of cholic acid was higher than that of $\beta$-muricholic acid. In the holoxenic rats, a nearly total disappearance of the bacterial metabolites of bile acids had already taken place.

\title{
LES MATIËRES AZOTÉES DES CONTENUS DE CAECUM DE RAT: MÉTHODE D'ÉTUDE ET RÉSULTATS OBTENUS : INFLUENCE DE L'ÉTAT AXÉNIQUE
}

\author{
R. PION, C. VALENZA et E. COMBE \\ Station d'Études des Métabolismes, \\ Centra de Recherches de Clermont-Ferrand, I. N.R. A., \\ 63 - Saint-Genès-Champanelle
}

En vue d'étudier la composition des matières azotées des contenus de cæcums des rats axéniques et holoxéniques, nous les avions dans un premier temps divisées en trois fractions : les composés solubles dans l'éthanol 82 p. roo, les composés insolubles dans l'éthanol et solubles dans l'acide trichloracétique à ıo p. soo (ATC), et le résidu insoluble dans ces deux solvants. Nous avons pu ainsi mettre en évidence certaines différences dans la répartition de l'azote entre ces fractions et leurs compositions en acides aminés chez les animaux axéniques et holoxéniques, ainsi que la liaison entre la composition des contenus de cæcums des rats axéniques et la nature et le taux protéique de la ration ingérée. Nous avons cherché à améliorer la technique de fractionnement, en effectuant préalablement à l'extraction par l'éthanol une solubilisation d'une partie des composés présents dans le chlorure de sodium 9 p. rooo, suivie d'une centrifugation (3o ooo $g$ ). Nous avons déterminé par chromatographie sur colonne au moyen d'un appareil automatique les compositions en acides aminés totaux des différentes fractions, ainsi que les compositions en acides aminés libres des extraits. Nous avons utilisé, pour l'estimation de la taille des molécules peptidiques présentes des séparations sur gel de "Sephadex » et sur "Biogel $P$ » ainsi que le dosage des groupements aminés libres.

Les extraits éthanoliques renferment la majorité des acides aminés libres et amides, associés à des peptides ; les extraits par l'ATC contiennent une proportion appréciable de certains acides aminés libres (acide aspartique, alanine, sérine et glutamine en particulier), des peptides et dans le cas des animaux axéniques, des protéines. Les contenus de cæcum des animaux axéniques 
renferment beaucoup plus d'acides aminés libres que ceux des animaux holoxéniques, mais la proportion de la lysine libre dans l'ensemble des acides aminés libres est très élevée dans le cas des rats holoxéniques.

Les peptides extraits par l'éthanol ont une longueur moyenne de chaîne plus faible que celle des peptides présents dans l'extrait par l'ATC; les peptides présents dans les deux extraits effectués à partir des contenus de cæcums des animaux axéniques ont une longueur de chaîne supérieure à celle des composés correspondants provenant des animaux holoxéniques. Les résidus d'extraction provenant des animaux axéniques ont une composition en acides aminés voisine de celle du tissu intestinal alors que ceux qui ont été obtenus dans le cas des animaux holoxéniques, qui renferment plus d'azote, ont une composition assez différente.

\section{SUMMARY}

\section{NITROGENOUS MATTER IN THE CAECAL, CONTENTS OF THE RAT : METHODS OF STUDY AND RESULTS OB'TAINED; INFLUENCE OF THE GERM FREE STATE}

The caecal contents of axenic (germ free) and holoxenic (conventional) rats have been divided into three fractions with a view to studying the nitrogenous matter - the compounds soluble in 82 p. Ioo ethanol, the compounds insoluble in ethanol but soluble in to p. roo trichloracetic acid (TCA), and the residue insoluble in these two solvents. Some differences between axenic and holoxenic animals in the distribution of nitrogen and in the composition of the amino acids between these fractions have thus been demonstrated, as well as the relationship between the composition of the cæcal contents of axenic rats and the nature and percentage of protein in the diet. The analytical technique has been improved by dissolving part of the components present in $9 \mathrm{p}$. I ooo sodium chloride followed by a centrifugation at $30000 \mathrm{~g}$ before the extraction with ethanol. The total amino acid composition of the different fractions and the free amino acids in the extracts have been determined by column chromatography using an automatic apparatus. Separations on "Sephadex " gel and "Biogel P " and the determination of the free amino groups have been employed for determining the size of the peptide molecules.

The ethanol extracts contain the main part of the amino acids and amides associaterd with peptides and of the free amino acids, and the TCA extracts contain quite a large proportion of certain free amino acids (particularly aspartic acid, alanine, serine and glutamine), peptides, and in the case of axenic animals, proteins. The cæcal contents of axenic animals contain markedly more free amino acids than those of holoxenic animals, but the proportion of free lysine in cæcal contents of holoxenic rats is very high.

The peptides extracted with ethanol have a shorter mean chain length than the peptides in the TCA extracts. The chain length of the peptides in the two extracts prepared from the cæcal contents of axenic animals is greater than that of the corresponding compounds derived from holoxenic animals. The amino acid composition of the extraction residues from axenic animals is similar to that of the intestinal tissue, while the residues obtained from holoxenic animals, which contain more nitrogen, differ in their amino acid composition. 